Article

\title{
Effect of Pig and Cattle Slurry Application on Heavy Metal Composition of Maize Grown on Different Soils
}

\author{
Giorgio Provolo *, Giulia Manuli, Alberto Finzi, Giorgio Lucchini, Elisabetta Riva and \\ Gian Attilio Sacchi
}

Department of Agricultural and Environmental Sciences, University of Milan, 20133 Milan, Italy; giulia.manuli@studenti.unimi.it (G.M.); alberto.finzi@unimi.it (A.F.); giorgio.lucchini@unimi.it (G.L.); elisabetta.riva@unimi.it (E.R.); gianattilio.sacchi@unimi.it (G.A.S.)

* Correspondence: giorgio.provolo@unimi.it

Received: 29 June 2018; Accepted: 30 July 2018; Published: 31 July 2018

\begin{abstract}
Cattle and pig manure contain useful mineral nutrients (N, P, and $\mathrm{K})$ and are therefore used as organic fertilizer. However, excessive applications of manure can cause environmental problems and threaten animal and human health because these materials also hold significant amounts of heavy metals, particularly $\mathrm{Cu}$ and $\mathrm{Zn}$. To assess the potential risk due to the increased concentrations of heavy metals ( $\mathrm{Cu}, \mathrm{Mn}, \mathrm{Zn}$, and $\mathrm{Cr}$ ) in a harvested crop, two maize hybrids were grown in pots on four different soils with three different fertilisers (urea, pig manure, and cattle manure). Both soil and manure characteristics influenced the heavy metal concentrations in the plant shoots. Organic fertilisation strongly interacted with the soils and, in general, reduced the shoot content of $\mathrm{Cu}, \mathrm{Mn}$, and $\mathrm{Zn}$. A preliminary assessment of the heavy metal balance of the agricultural systems based on the intensive livestock production and maize cultivation showed that the potential soil enrichment of the long-term application of livestock manure arises mainly from the application of pig slurries that have a high content of $\mathrm{Cu}$ and $\mathrm{Zn}$. The time required to apply an amount of metal that is equal to the initial soil content is 60-300 years for $\mathrm{Zn}$ and 240-450 years for $\mathrm{Cu}$, depending on the soil type and the initial heavy metal content.
\end{abstract}

Keywords: Nutrient recycling; Food chain; Land application; Plant uptake; Livestock manure

\section{Introduction}

Livestock manure is traditionally recognised as a valuable fertiliser and until the beginning of the 20th century, manure application was the only method for enriching the soil. The use of manure to supply nutrients to crops is considered as the best solution to close the nutrient cycle and to reduce the use of mineral fertilisers [1,2]. The intensification of cattle and pig farming has caused increasing concern about the soil enrichment that is connected with the management of livestock manure $[3,4]$.

The most evident risk of pollution is related to nitrogen $(\mathrm{N})$ and phosphorus $(\mathrm{P}) . \mathrm{N}$ can be emitted into the air as ammonia and can cause pollution to the groundwater, mainly as nitrate. The surface and subsurface movement of $\mathrm{N}$ from the soil to the surface water, often connected with $\mathrm{P}$ transport, is the main cause of eutrophication [1]. Most of the guidelines and regulations for the reduction of the impact of livestock manure use suggest limits that are close to the amount of $\mathrm{N}$ (but sometimes also $\mathrm{P}$ ) that is actually required by crops. Although livestock manure is recognised as valuable fertiliser, the application of the manure to meet a particular nutrient demand may lead (in long-term applications) to excessive accumulations of other elements in the soil, particularly heavy metals (HM) such as copper $(\mathrm{Cu})$, zinc $(\mathrm{Zn})$, and manganese $(\mathrm{Mn})[5,6]$. At adequate concentrations, these elements are essential 
for the plant life cycle, however in excess of specific threshold ranges, the metals become toxic for the edaphic organisms and crops. Furthermore, when HM enter the food chain, they pose risks for animals and humans [4,7]. This risk could induce a future restriction on manure use unless specific precautions are taken and/or reliable HM input-output balance evaluations are conducted, both at farm and district scales.

The prolonged application of HM to the soil can also lead to a reduction of soil buffering capacity and, as such, can cause permanent contamination of the soil and groundwater [8]. The content of HM in livestock manure can vary greatly among animal species and diets. Animal diets contain a higher content of HM than plants.

Some HMs, especially $\mathrm{Cu}$ and $\mathrm{Zn}$, are added to the diet to enhance animal performance and provide protection against bacterial infections. The addition of mineral supplements to the diet is also a possible source of HMs [1,2].

The great variation of HM concentrations in manure confirms the strong influence of the diets and the species on HM excretion by animals. Thus, to assess the possible effects of manure application on the introduction of HM into the food chain, studies should consider the different types of manure. In particular, pig manure typically has a higher content of $\mathrm{Cu}$ and $\mathrm{Zn}$ compared to cattle manure [1].

Once added to the soil, HMs are subject to reactions that modify their bioavailability for the plants. Indeed, depending on the soil chemical-physical characteristics, processes such as adsorption on clay and/or organic surface-active components, precipitation as insoluble salts (carbonate and phosphate), and oxidation state changes affect HM solubility [9]. Prolonged application of HM can also lead to a reduction of soil buffering capacity causing permanent contamination of the soil and the leaching of HMs towards the groundwater [8]. Nevertheless, it has also been reported [10] that organic amendments such as cattle manure can serve as soil HM ameliorants. Indeed, the application of organic matter $(\mathrm{OM})$ as amendments to soils is an effective strategy for heavy metal immobilization through complexation with components of OM, thus possibly reducing plant uptake [11].

Because they are essential for plant growth, some HMs are absorbed by the root and are translocated to the shoot by specific transport mechanisms that, in some circumstances, mediate the movement of nonessential $\mathrm{HMs}$ such as $\mathrm{Pb}$ and $\mathrm{Cd}$. Both the activity and the selectivity of these mechanisms are finely regulated by specific genetic traits, which implies that the uptake and accumulation of soil bioavailable HM fractions in the leaves vary greatly among plant species and also among different genotypes within the same species [12-14]. Excluding specific groups of plant species known as accumulator or hyperaccumulator plants, most (>90\%) of the absorbed HMs are retained in the roots and thus, only a minor fraction is translocated and accumulated in the shoot [15].

The removal efficiency of soil HMs by crops is determined by the concentration of these elements in the shoots, by the total developed biomass, and by the number of possible seasonal growth cycles [16-18]. Maize (Zea mays L.), together with wheat and rice, is one of the most commonly cultivated cereals and crops in the world with 188 million ha cultivated and 1 billion metric tons produced in 2016 [19]. Maize is used as a typical cereal plant, both for human nutrition and for animal feed.

Various authors have shown that maize is a crop with a relatively high HM uptake and tolerance capacity. Berenguer et al. [6] found concentrations of $15.7 \mathrm{mg} \mathrm{kg}^{-1}$ and $1.74 \mathrm{mg} \mathrm{kg}^{-1}$ for $\mathrm{Zn}$ and Cu, respectively. Furthermore, Aliyu and Adamu [20] showed $\mathrm{Zn}, \mathrm{Mn}$, and $\mathrm{Cr}$ concentrations in dry matter of $16.88 \mathrm{mg} \mathrm{kg}^{-1}, 2.54 \mathrm{mg} \mathrm{kg}^{-1}$, and $3.91 \mathrm{mg} \mathrm{kg}^{-1}$, respectively. Elevated levels of HM in the soil may result in increased uptake by plants, which may be consumed by animals $[8,21]$.

Therefore, crop uptake of HM can be affected by several factors among which the type of plant, the type of soil, and the characteristics of the manure that is applied may have relevant roles. To better understand the effect of these factors on the accumulation of HM in a harvested crop, a study was conducted using two maize hybrids characterized by different growth-cycle durations which were grown in pots on four different soils with three different fertiliser sources (urea, pig slurry, and cattle slurry) under controlled (greenhouse) and uncontrolled (outdoors) environmental conditions. The 
principal objective of the study was to determine the effects of cattle and pig manure on essential $(\mathrm{Cu}, \mathrm{Mn}, \mathrm{Zn})$ and nonessential $(\mathrm{Cr})$ heavy metal element compositions in two hybrids of maize plants. A further aim was the definition of an input-output balance of these elements for the maize crops in an intensive livestock environment. The results were to be used to evaluate the soil enrichment of HM in an intensive livestock area that was based on the possible higher input of HMs in the food chain due to slurry application.

\section{Materials and Methods}

Two experimental trials were conducted in 2016. In both cases, maize (Zea mays L.) plants were grown in pots for 50 days after being sowed in a greenhouse (2 May-20 June, experiment 1 ) or in open air (18 July-5 September, experiment 2 ). Three experimental variables were considered: soil type, fertilization treatments, and maize hybrids characterised according to the Food and Agriculture Organization of the United Nations (FAO) classification.

Four field soils that had been subjected to different fertilization practices were utilised. Soil A and soil B were collected from a pig farm located in North Italy (Province of Lodi) on the border with the Po embankment. Soil A had been subjected only to mineral fertilization for the previous 15 years, whereas Soil B had a long history of treatment with animal manure. Soil C was collected from a paddy field located at the Rice Experimental Centre of CREA in Vercelli (Italy) and had not received slurry in recent years. Soil D was collected from a field with a long history of manure treatments located in Landriano (Pavia, North Italy) at the Menozzi experimental farm of the University of Milan.

The soil samples were collected using a blade from the top $20 \mathrm{~cm}$ of depth and were oven dried for $24 \mathrm{~h}$ at $80^{\circ} \mathrm{C}$. The soils' general chemical-physical properties were determined as follows: texture by pipette method, $\mathrm{pH}$ in aqueous solution using a 1:2.5 sample/water ratio, total nitrogen (TKN) by the Kjeldahl method, and total organic carbon by dichromate methods. For Cation Exchange Capacity determination, the samples were saturated with $\mathrm{BaCl}_{2}$-triethanolamine solution ( $\mathrm{pH} \mathrm{8.1)}$. The total concentrations of essential $(\mathrm{Zn}, \mathrm{Mn}$, and $\mathrm{Cu}$ ) and nonessential $(\mathrm{Cr}) \mathrm{HMs}$ in the soils were determined by inductively coupled plasma mass spectrometry (ICP-MS, Bruker Aurora-M90) which was preceded by acid digestion of the samples according to standard procedures [22,23]. Each soil was fertilized with three different nutrient sources: pig slurry, dairy cattle slurry, or urea. Each combination of soil-fertilization served as a growth substrate for two different maize hybrids: a late-flowering hybrid (hybrid a: FAO class 700) and an early-flowering hybrid (hybrid b: FAO class 300). The maize plants were grown in 9-L pots containing $8 \mathrm{~kg}$ of soil. The pots (96 in total) were placed to give 8 plants $\mathrm{m}^{-2}$ in four repetitions, and each of them were arranged in randomized blocks. In each pot, three seeds were sown and after the emergence, two plantlets were removed. In both experiments, each pot received $200 \mathrm{~kg} \mathrm{ha}^{-1}$ of $\mathrm{N}$ either in pig slurry, dairy cattle slurry, or urea.

Dairy cattle and pig slurries were collected from a dairy cow farm located in Landriano (Pavia, Italy) and from a fattening pig farm located in the province of Lodi, respectively. To have fresh material, both manures were collected just prior to each test and their chemical-physical properties being established. Slurry analyses ( $\mathrm{pH}$ value; dry matter, total solids, volatile solids; ammonia nitrogen and total Kjeldahl nitrogen content) were carried out according to standard methods [23]. Moreover, the total contents of $\mathrm{Ca}, \mathrm{Cu}, \mathrm{Mn}, \mathrm{Zn}$, and $\mathrm{Cr}$ in the slurries were evaluated using ICP-MS spectroscopy after acid mineralisation [22,23].

The plants were sampled 50 days after sowing. The maize shoots were excised and were oven dried at $80{ }^{\circ} \mathrm{C}$ for 24 hours. Then, they were ground to produce homogeneous and representative powdered samples. During the vegetative growth period, weekly non-destructive evaluations of the plants' physiological statuses were performed. Leaf total chlorophyll content $(\mathrm{ChL})$ and fluorescence emission were measured using the Dualex ${ }^{\circledR}-4$ (Force-A, Orsay Cedex, France) and the Handy-PEA (Hansatech, Norfolk, UK) devices, respectively.

For ion analysis, carried out in duplicate, aliquots $(0.5 \mathrm{~g})$ of dry powdered maize shoot samples were digested by a microwave digestion system (Anton Paar MULTIWAVE-ECO) in Teflon tubes 
that were filled with $10 \mathrm{~mL}$ of $65 \% \mathrm{HNO}_{3}$ by applying a one-step temperature ramp (increasing to $210{ }^{\circ} \mathrm{C}$ in $10 \mathrm{~min}$, maintained for $10 \mathrm{~min}$ ). After a cooling time of $20 \mathrm{~min}$, the mineralized samples were transferred into polypropylene test tubes. The samples were diluted to $1: 40$ with $1.3 \mathrm{M} \mathrm{HNO}_{3}$ in MILLI-Q water and the concentration of the elements was measured by ICP-MS. An aliquot of a $2 \mathrm{mg} \mathrm{L}^{-1}$ internal standard solution $\left({ }^{72} \mathrm{Ge},{ }^{89} \mathrm{Y},{ }^{159} \mathrm{~Tb}\right)$ was added to the samples, and a calibration curve was used to give a final concentration of $20 \mu \mathrm{gL}^{-1}$. Polyatomical analysis interferences were removed using CRI (Collision-Reaction-Interface) with an $\mathrm{H}_{2}$ flow of $70 \mathrm{~mL} \mathrm{~min}^{-1}$ through the skimmer cone.

A randomized design was used for the experiment. Statistical analysis was completed using SPSS v. 25 software (IBM Corp., Armonk, NY, USA). A descriptive statistical analysis was performed on all of the data, and the results were expressed as means and standard deviations. The data were also subjected to analysis of variance (ANOVA) using a full factorial model, using maize genotype, soils, and fertilisation as the fixed factors. The homogeneity of the variances has been checked with the Levene's test. The significant treatments were compared by utilizing Tukey's HSD multiple range test $(p<0.05)$.

To evaluate the possible soil enrichment of HMs in an intensive livestock environment, a balance between crop uptake, derived from the experiment results, and the assumed contributions from the manure application, was calculated. For this purpose, a manure application that was equivalent to $200 \mathrm{~kg} \mathrm{ha}^{-1}$ of total $\mathrm{N}$ was considered, and the average characteristics of the two manures used in the experiment were used. Crop uptake of HM was calculated considering the HM content in the maize shoots for the different soil conditions with the different fertilization systems in experiment 2 . The $\mathrm{HM}$ uptakes by the two maize hybrids were averaged and an average silage yield of $20 \mathrm{tha}^{-1}$ of dry matter was assumed. The balance was calculated both in terms of absolute values $\left(\mathrm{g} \mathrm{ha}^{-1}\right)$ and as a fraction of the initial soil content of the HM elements, considering a soil depth of $0.4 \mathrm{~m}$ (the average rooting depth for maize).

\section{Results}

\subsection{Characteristics of Soils and Slurries}

The general chemical-physical characteristics of the soils that were utilised in the experiments are reported in Table 1.

Table 1. General chemical-physical properties of the soils before being sown with maize.

\begin{tabular}{|c|c|c|c|c|}
\hline & Soil A & Soil B & Soil C & Soil D \\
\hline Texture & Silt loam & Sandy loam & Loam & Loam \\
\hline sand $(\%)$ & $21 \pm 1$ & $66 \pm 1$ & $40 \pm 1$ & $44 \pm 7$ \\
\hline silt $(\%)$ & $59 \pm 1$ & $27 \pm 3$ & $47 \pm 2$ & $42 \pm 7$ \\
\hline clay $(\%)$ & $20 \pm 0$ & $7 \pm 2$ & $13 \pm 2$ & $14 \pm 1$ \\
\hline $\mathrm{pH}_{(\mathrm{H} 2 \mathrm{O})}$ & $7.8 \pm 0.1$ & $7.2 \pm 0.1$ & $6.4 \pm 0.1$ & $6.6 \pm 0.1$ \\
\hline $\operatorname{CEC}\left(\mathrm{cmol}^{+} \mathrm{kg}^{-1}\right)$ & $14.6 \pm 0.3$ & $8.1 \pm 0.2$ & $8.6 \pm 0.1$ & $15.8 \pm 0.3$ \\
\hline $\mathrm{OM}\left(\mathrm{mg} \mathrm{g}^{-1}\right)$ & $23.5 \pm 0.8$ & $18.3 \pm 0.6$ & $19.3 \pm 0.7$ & $29.9 \pm 0.9$ \\
\hline $\mathrm{Ca}\left(\mathrm{g} \mathrm{kg}^{-1}\right)$ & $47.4 \pm 0.8$ & $31.2 \pm 1.7$ & $5.6 \pm 0.8$ & $3.6 \pm 0.4$ \\
\hline $\mathrm{Cu}\left(\mathrm{mg} \mathrm{kg}^{-1}\right)$ & $42.7 \pm 2.6$ & $45.9 \pm 2.2$ & $27.1 \pm 2.9$ & $53.0 \pm 2.4$ \\
\hline $\mathrm{Mn}\left(\mathrm{mg} \mathrm{kg}^{-1}\right)$ & $840.9 \pm 8.3$ & $508.3 \pm 29.8$ & $306.5 \pm 19.0$ & $369.3 \pm 17.5$ \\
\hline $\mathrm{Zn}\left(\mathrm{mg} \mathrm{kg}^{-1}\right)$ & $106.4 \pm 4.7$ & $152.0 \pm 12.6$ & $55.7 \pm 4.5$ & $255.7 \pm 7.0$ \\
\hline $\mathrm{Cr}\left(\mathrm{mg} \mathrm{kg}^{-1}\right)$ & $221.1 \pm 3.3$ & $149.1 \pm 11.7$ & $167.9 \pm 15.3$ & $65.0 \pm 5.3$ \\
\hline
\end{tabular}

CEC: Cation exchange capacity; OM: Organic matter. Data are the means and the standard deviations of three analytical replicates.

The four soils were quite different in their chemical-physical properties, reflecting not only their different origins, but also their different histories concerning fertilizer treatments. This diversity enhanced the suitability of the soils according to the objective of the research. In particular, soil D (with 
a history of cattle manure applications) showed the highest contents of $\mathrm{OM}, \mathrm{Zn}$, and $\mathrm{Cu}$. Soils $\mathrm{B}$ and $\mathrm{D}$ had a neutral $\mathrm{pH}$, while soil A was slightly alkaline and soil $\mathrm{C}$ was slightly acidic.

The general chemical-physical characteristics of the manure that was utilised in the two experiments are reported in Table 2.

Table 2. General chemical-physical properties of the slurries used in the two experiments.

\begin{tabular}{ccccc}
\hline & \multicolumn{2}{c}{ Experiment 1 } & Experiment 2 \\
\hline & Pig slurry & Cattle slurry & Pig slurry & Cattle slurry \\
$\mathrm{pH}$ & $7.3 \pm 0.1$ & $6.8 \pm 0.1$ & $7.7 \pm 0.1$ & $6.4 \pm 0.1$ \\
$\mathrm{DM} \mathrm{( \% )}$ & $2.9 \pm 0.1$ & $9.7 \pm 0.1$ & $3.0 \pm 0.1$ & $7.0 \pm 0.1$ \\
$\mathrm{VS}(\% \mathrm{DM})$ & $63 \pm 1$ & $85 \pm 1$ & $57 \pm 1$ & $82 \pm 1$ \\
$\mathrm{~N}-\mathrm{NH}_{4}^{+}\left(\mathrm{g} \mathrm{kg}^{-1} \mathrm{fw}\right)$ & $2.1 \pm 0.00$ & $1.6 \pm 0.02$ & $2.6 \pm 0.02$ & $1.4 \pm 0.00$ \\
$\mathrm{TKN}\left(\mathrm{g} \mathrm{kg}^{-1} \mathrm{fw}\right)$ & $3.1 \pm 0.02$ & $3.8 \pm 0.03$ & $3.7 \pm 0.03$ & $2.9 \pm 0.05$ \\
$\mathrm{Ca}\left(\mathrm{g} \mathrm{kg}^{-1}\right)$ & $31.1 \pm 1.7$ & $11.9 \pm 0.9$ & $35.8 \pm 0.8$ & $16.1 \pm 1.5$ \\
$\mathrm{Cu}\left(\mathrm{mg} \mathrm{kg}^{-1}\right)$ & $459 \pm 19$ & $21 \pm 4$ & $295 \pm 10$ & $26 \pm 2$ \\
$\mathrm{Mn}\left(\mathrm{mg} \mathrm{kg}^{-1}\right)$ & $579 \pm 11$ & $110 \pm 5$ & $736 \pm 11$ & $149 \pm 6$ \\
$\mathrm{Zn}\left(\mathrm{mg} \mathrm{kg}^{-1}\right)$ & $3740 \pm 43$ & $204 \pm 23$ & $1923 \pm 21$ & $216 \pm 14$ \\
$\mathrm{Cr}\left(\mathrm{mg} \mathrm{kg}^{-1}\right)$ & $12 \pm 1$ & $28 \pm 2$ & $12 \pm 1$ & $45 \pm 1$ \\
\hline
\end{tabular}

DM: Dry matter; VS: Volatile solids; TKN: Total Kjeldahl Nitrogen; N-NH4+: Ammonia Nitrogen; fw: fresh weight. Data are the means and standard deviations of three analytical replicates.

Although some minor differences in the main chemical-physical properties of the slurries existed, these were within the range that was previously reported for manure produced in the regional area of origin $[24,25]$. However, with regard to heavy metals, the pig slurry had a high content of Zn compared to the values that were reported by other authors $[1,3,25]$. High values of $\mathrm{Zn}$ concentration are not unusual for this type of livestock (farrow to fattening). Considering the dilution of the slurry and the application rate, the amount of $\mathrm{Zn}$ that was applied to the soil with this slurry is comparable to the dose applied with other pig slurries.

\subsection{HM Content in Maize Shoots}

In all cases, HMs never reached the threshold concentrations that are considered toxic for the plants, and these results were corroborated by the absence of morphological and physiological symptoms in the maize shoots that are specifically ascribable to excess amounts of each of the elements considered [26]. A trend for higher concentrations of the four HMs in the shoots of the plants that were undergoing urea fertilization was apparent (Figures 1-4). This behaviour might be explained by taking into account that some of the compounds present in the animal manure, such as phytate and/or phenols, could bind with the HMs, making them less available for plant uptake [27]. Furthermore, urea hydrolysis can induce a more pronounced acidification of soil, and in turn, a higher solubility of soil HMs, than occurs from the mineralization of organic fertilizers [28].

Table 3 summarizes the results of the statistical analysis of the significance in the treatments and between the treatments (soil, fertilization, and maize genotype) in the two experiments. The elements for which a statistically significant difference was found between the two maize hybrids showed a higher concentration in the shoots of the early genotype (b: FAO class 300), with the exception of Mn in the plants that were grown on soil $\mathrm{D}$ and of $\mathrm{Zn}$ in the plants that were grown on soil $\mathrm{B}$. 


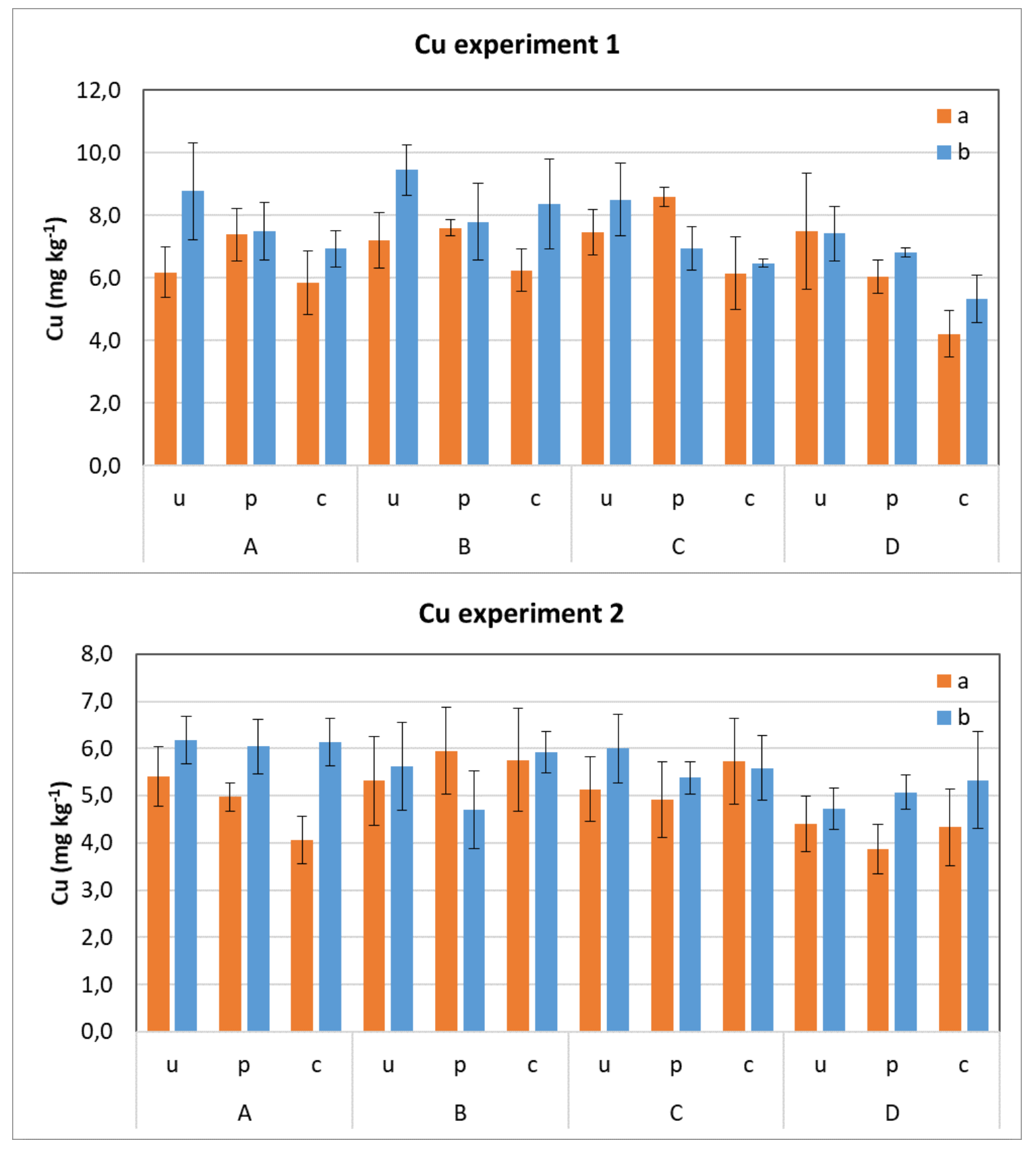

Figure 1. Concentrations of $\mathrm{Cu}(\mathrm{mg} / \mathrm{kg})$ in the maize shoots (genotype a and genotype b) during experiment 1 (top) and experiment 2 (bottom). A, B, C, and D are the different soils; $u, p$, and c are urea, pig slurry, and cattle slurry fertiliser treatments, respectively. Vertical bars represent the standard deviations. 


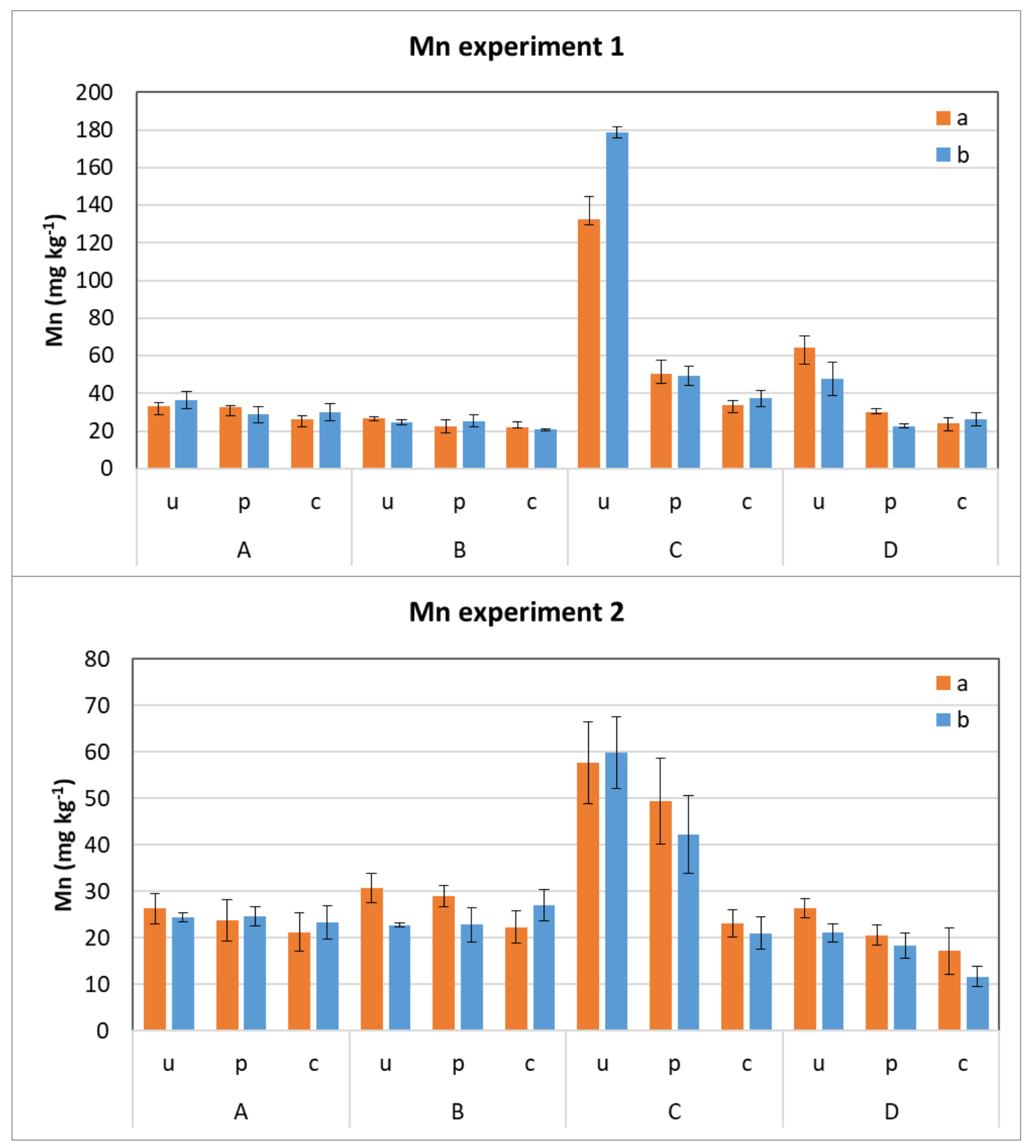

Figure 2. Concentrations of $\mathrm{Mn}(\mathrm{mg} / \mathrm{kg})$ in the maize shoots (genotype a and genotype b) during experiment 1 (top) and experiment 2 (bottom). A, B, C, and D are the different soils; $\mathrm{u}, \mathrm{p}$, and c are urea, pig slurry, and cattle slurry fertiliser treatments, respectively. Vertical bars represent the standard deviations. 

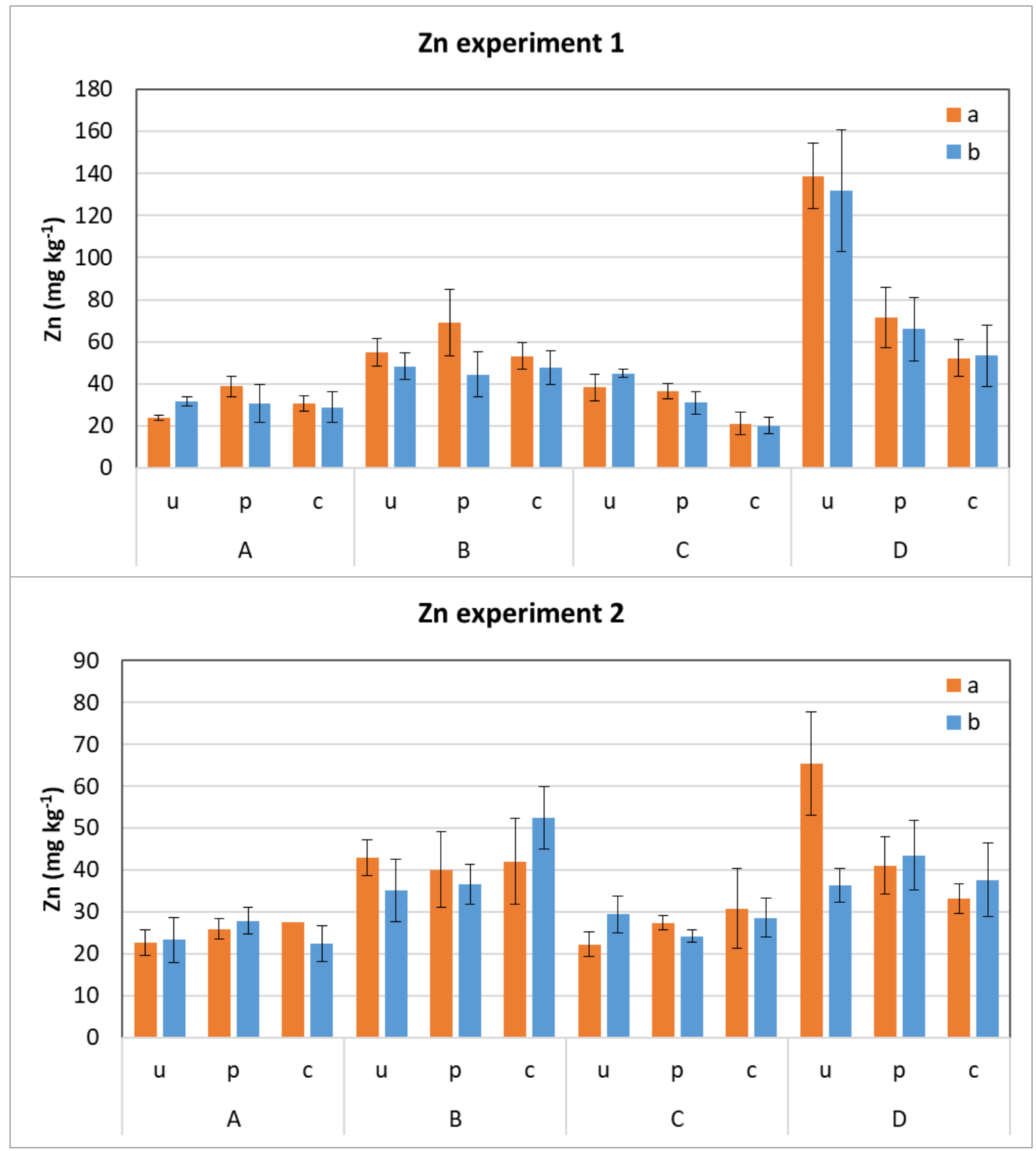

Figure 3. Concentrations of $\mathrm{Zn}\left(\mathrm{mg} \mathrm{kg}^{-1}\right)$ in the maize shoots (genotype a and genotype b) during experiment 1 (top) and experiment 2 (bottom). A, B, C, and D are the different soils; $u, p$, and c are urea, pig slurry, and cattle slurry fertiliser treatments, respectively. Vertical bars represent the standard deviations. 


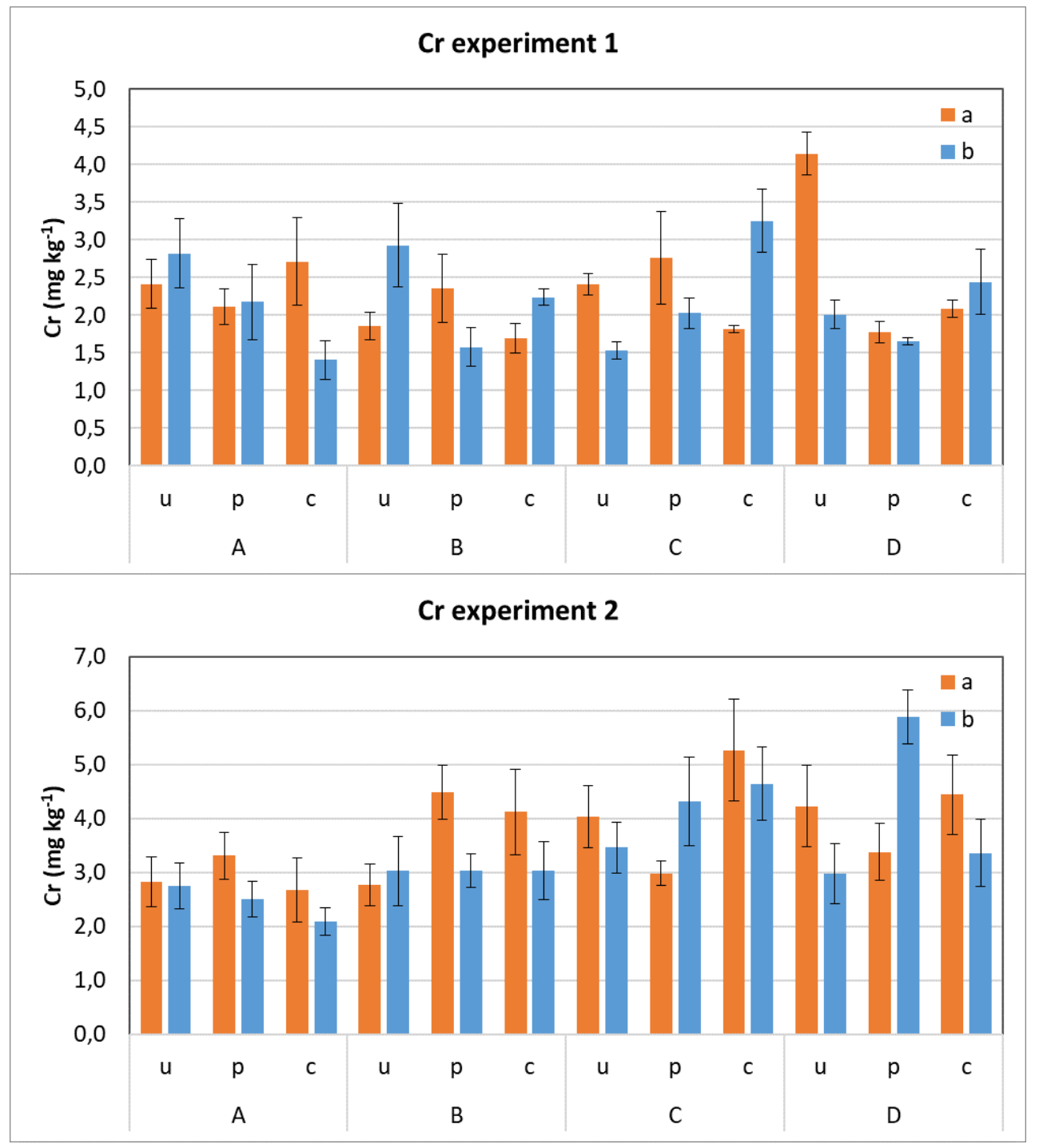

Figure 4. Concentrations of $\mathrm{Cr}\left(\mathrm{mg} \mathrm{kg}^{-1}\right)$ in the maize shoots (genotype a and genotype b) during experiment 1 (top) and experiment 2 (bottom). A, B, C, and D are the different soils; $\mathrm{u}, \mathrm{p}$, and c are urea, pig slurry, and cattle slurry fertiliser treatments, respectively. Vertical bars represent the standard deviations.

Table 3. Statistical analysis of the significance of the effects of the treatments and between the treatments (soil, fertilization, and maize flowering period) in the two experiments.

\begin{tabular}{|c|c|c|c|c|c|c|c|c|}
\hline & $n$ & Soil (s) & Fertilization (f) & Maize (g) & $\mathbf{s} \times \mathbf{f}$ & $\mathbf{s} \times \mathbf{g}$ & $f \times g$ & $\mathbf{s} \times \mathbf{f} \times \mathbf{g}$ \\
\hline \multicolumn{9}{|c|}{ Experiment 1} \\
\hline $\mathrm{Cu}$ & 86 & $* * *$ & $* * *$ & $* * *$ & n.s. & n.s. & * & n.s. \\
\hline $\mathrm{Mn}$ & 90 & $* * *$ & $* * *$ & * & $* * *$ & $* * *$ & $* * *$ & $* * *$ \\
\hline $\mathrm{Zn}$ & 86 & $* * *$ & $* * *$ & n.s. & $* * *$ & n.s. & n.s. & n.s. \\
\hline $\mathrm{Cr}$ & 70 & n.s. & $* * *$ & * & $* * *$ & $* *$ & $* *$ & $* * *$ \\
\hline \multicolumn{9}{|c|}{ Experiment 2} \\
\hline $\mathrm{Cu}$ & 90 & $* * *$ & n.s. & $* * *$ & n.s. & $* *$ & n.s. & n.s \\
\hline $\mathrm{Mn}$ & 93 & $* * *$ & $* * *$ & $*$ & $* * *$ & n.s. & n.s & n.s \\
\hline $\mathrm{Zn}$ & 80 & $* * *$ & n.s. & n.s. & $* * *$ & n.s & $*$ & $* * *$ \\
\hline $\mathrm{Cr}$ & 83 & $* * *$ & $* * *$ & * & $* * *$ & n.s & $* * *$ & $* * *$ \\
\hline
\end{tabular}


In the case of $\mathrm{Cu}$, for which shoot concentrations ranged from 3.8 to $9.0 \mathrm{mg} \mathrm{kg}^{-1} \mathrm{DW}$ (Figure 1), the urea fertilization had a significant influence only in experiment 1 and in the plants that were grown on soils C and D. In both experiments, Mn was markedly accumulated in the shoots of the plants that were grown on soil $\mathrm{C}$ under urea fertilization, and the levels were similar for the two maize hybrids (>120 mg kg ${ }^{-1} \mathrm{DW}$ and about $60 \mathrm{mg} \mathrm{kg}^{-1} \mathrm{DW}$ in experiments 1 and 2, respectively-Figure 2). The shoot concentrations of Zn ranged within the interval 20-135 mg kg${ }^{-1} \mathrm{DW}$ (Figure 3), and no significant differences were found between the values that were measured in the two maize hybrids, except for the plants in experiment 2 that were grown on soil D under urea fertilization (for which higher concentrations were observed in the FAO class 700 hybrid).

Cr causes serious environmental concern [29] and the $\mathrm{Cr}$ (VI) form particularly exerts toxicity in plants and animals. Therefore, monitoring the eventual presence of $\mathrm{Cr}$ in animal manure that is used in agriculture is essential. In the manure that was used in this research, the total $\mathrm{Cr}$ concentrations ranged in the interval $12-45 \mathrm{mg} \mathrm{kg}^{-1}$, whereas $\mathrm{Cr}$ in the soils ranged in the interval $65-221 \mathrm{mg} \mathrm{kg}^{-1}$ (Figure 4). Considering both of the experiments and all of the treatments, there was no particular trend in $\mathrm{Cr}$ accumulation in the maize shoots. The maximum $\mathrm{Cr}$ concentration was approximately $6 \mathrm{mg} \mathrm{kg}^{-1}$ in experiment 2 in the shoots of the earlier flowering maize hybrid (FAO class 300) which was grown in soil $\mathrm{D}$ under cattle slurry application.

The type of fertilization significantly influenced the shoot concentrations of all of the elements that were analysed (Table 3). In addition, the type of soil significantly affected the shoot concentrations of all HMs except $\mathrm{Cr}$ (in experiment 1). Likewise, the length of the emergence-flowering period (i.e., plant genotype) significantly affected the shoot concentrations of all HMs except Zn. Considering the combined effects of the three treatments (soil, fertilization, and maize hybrid), a complex picture of interactions resulted. Statistically significant interactions resulted: (a) between soil and fertilization for all of the metals, excluding $\mathrm{Cu}$; (b) between soil and maize hybrid in the cases of $\mathrm{Mn}$ and $\mathrm{Cr}$; (c) between the type of fertilization applied and maize hybrid for all of the metals, excluding $\mathrm{Zn}$; and d) among soil, the fertilization applied, and maize hybrid in the cases of $\mathrm{Mn}$ and $\mathrm{Cr}$, but not for $\mathrm{Cu}$ and $\mathrm{Zn}$.

Although the same general trends were observed in both experiments, some different results from the statistical analysis were obtained in experiment 2 (conducted in open-air conditions) (Table 3 ). Indeed, excluding $\mathrm{Cr}$, although the effects of soil and maize hybrid on HMs were similar to those observed in experiment 1 , there was no significant effect of the type of fertilization that was applied on the shoot concentrations of $\mathrm{Cu}$ and $\mathrm{Zn}$. However, considering the combined effects among the treatments, only the combination "soil type vs. fertilization applied" confirmed the behaviours that were observed in experiment 1.

The discrepancies between the results from the two experiments might be due to the different environmental growth conditions, although the physiological status of the plants was similar for all of the treatments, however the overall trends, especially for $\mathrm{Cu}$ and $\mathrm{Zn}$ (Figures 2 and 3), were observed in both experiments.

\subsection{HM Balance}

Figure 5 summarizes the HM balances for the different soils and fertilisers that were used. As expected, for all of the elements and the soils that were considered, the growth of the plants that were exposed to mineral (i.e., urea) fertilisation created a negative balance with a consequent impoverishment of the soil in terms of HMs. The values found are in agreement with those of Aliyu and Adamu [20] for urea fertilization. 

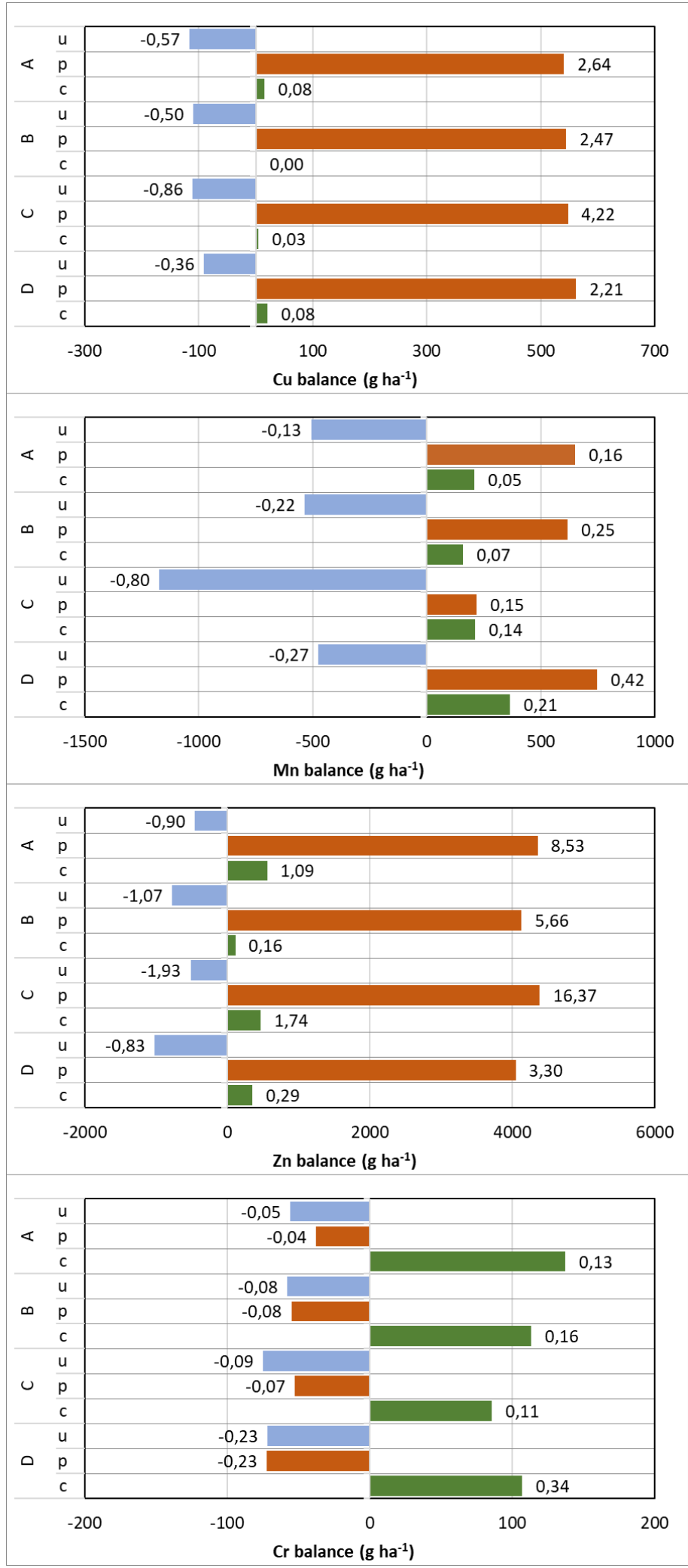

Figure 5. Mass balance between $\mathrm{Cu}, \mathrm{Mn}, \mathrm{Zn}$, and $\mathrm{Cr}$ added in fertilisers and removed by crop uptake. The numbers beside each bar represent the proportion expressed in $\mathrm{g} \mathrm{kg}^{-1}$ of the total soil content considering a soil layer of $0.4 \mathrm{~m}$. A, B, C, and D are the different soils; $\mathrm{u}, \mathrm{p}$, and c are urea, pig slurry, and cattle slurry fertiliser treatments, respectively. 
The amount of $\mathrm{Cu}$ added when pig slurry was applied was more than five times larger than the crop uptake, and in all cases, it was greater than $0.5 \mathrm{~kg} \mathrm{ha}^{-1}$, resulting in a positive balance for this HM. The enrichment of the soil represents $2.21-4.22 \mathrm{~g} \mathrm{~kg}^{-1}$ of the soil content (Figure 5). The use of cattle slurry, at the application rate that was considered in this evaluation, resulted in a slightly positive balance that was close to zero, showing that the contribution of $\mathrm{Cu}$ in cattle slurry completely satisfied (and slightly exceeded) the crop uptake.

The results that are related to the Mn balance are somewhat different (Figure 5). When mineral fertiliser was applied, the balance was of course negative, with a maximum crop uptake of $1.1 \mathrm{~kg} \mathrm{ha}^{-1}$ on soil C (which was also the soil with the lowest content of this element). When either pig or cattle slurry was applied, the balance was always positive, and in soil $\mathrm{C}$, the imbalance reached approximately $0.2 \mathrm{~kg} \mathrm{ha}^{-1}$. With pig slurry, the imbalance increased to a maximum of $0.7 \mathrm{~kg} \mathrm{ha}^{-1}$ for soil D. In all of the cases examined, the possible increase of $\mathrm{Mn}$ in the soil was limited. The highest positive value of the balance (soil D with pig slurry) represented only $0.42 \mathrm{~g} \mathrm{~kg}^{-1}$ of the soil content.

The results for $\mathrm{Zn}$ were somewhat similar to those for $\mathrm{Cu}$. There was a strong contribution of $\mathrm{Zn}$ when pig slurry was applied (more than $4 \mathrm{~kg} \mathrm{ha}^{-1}$ ), however lesser amounts $\left(0.1-0.6 \mathrm{~kg} \mathrm{ha}^{-1}\right.$ ) with cattle slurry (Figure 5). The amount of $\mathrm{Zn}$ left in the soil represented a significant proportion of the soil content, reaching $16 \mathrm{~g} \mathrm{~kg}^{-1}$ in soil C. (Figure 5).

The $\mathrm{Cr}$ balance was negative under urea fertilization and pig slurry fertilization, however it was positive when cattle slurry was used. However, the increase of $\mathrm{Cr}$ in the soil receiving cattle slurry was limited and represented only $0.11-0.34 \mathrm{~g} \mathrm{~kg}^{-1}$ of the soil content (Figure 5). In soils B and D, although the application of pig slurry resulted in a negative $\mathrm{Cr}$ balance, the balance was very close to that resulting from urea fertilisation due to increased crop uptake. The highest crop uptake (118 $\left.\mathrm{g} \mathrm{Cr} \mathrm{ha}^{-1}\right)$ occurred in soil D when pig slurry was applied. As noted previously, the application of pig slurry may facilitate Cr uptake by plants, especially when the soil Cr content is limited (as in soil D).

\section{Discussion}

The results of this study show that the absorption (uptake) of $\mathrm{Cu}, \mathrm{Mn}, \mathrm{Zn}$, and $\mathrm{Cr}$ by maize is a variable phenomenon and is influenced by several factors. In general, the results from experiment 1 , which was carried out under controlled conditions in a greenhouse, matched the results that were obtained in experiment 2, which was conducted outdoors and simulated the field conditions of maize cultivation.

Many authors have suggested that the application of organic fertilizers, such as livestock manure and slurries, greatly increases the amount of nutrients available to crops and that this is a reason for the greater maize absorption of HMs when organic fertilizer is applied [10,30,31]. Results from this study demonstrate that important uptake of HMs by maize occurred with urea (i.e., mineral) fertilization, and this is in accordance with findings by Putwattana et al. [11].

The soils with a long history of slurry application (B and $D)$ were associated with higher contents of $\mathrm{Zn}$ in maize shoots, despite being different in $\mathrm{pH}$ and total $\mathrm{Zn}$ content. However, the influence of long-term organic fertilisation seems not applicable to $\mathrm{Cu}$ uptake because the maize shoots showed similar $\mathrm{Cu}$ contents when they were grown on the different soils and with the different fertilisations that were applied.

Limited Mn concentrations were found in the shoots of maize that were grown on soil D, which was probably due to the higher content of organic matter and $\mathrm{Cu}$ content in this soil compared to the others. Both factors influence the availability of Mn for plant absorption [15].

The two hybrids of maize revealed a highly statistically significant difference in the shoot concentrations of the elements only in some cases, but especially for $\mathrm{Cu}$. Where differences in $\mathrm{HM}$ uptake occurred, the late-flowering maize genotype (FAO class 700) presented the lower concentrations. This hybrid probably had a smaller and slower need to absorb nutrients due to its longer physiological growth time. 
Regarding the HM balance, pig slurry supplied large amounts of $\mathrm{Cu}$ and $\mathrm{Zn}$, while the cattle slurry supplied amounts that approximately compensated for crop uptake. The balance for $\mathrm{Cr}$ was positive when cattle slurry was applied. The results that were obtained are partially in line with those obtained by other authors. Nicholson et al. [3] reported that an application of $250 \mathrm{~kg} \mathrm{ha}^{-1}$ of $\mathrm{N}$ with pig slurry made a contribution of $2.2 \mathrm{~kg} \mathrm{ha}^{-1} \mathrm{Zn}$ and $1.6 \mathrm{~kg} \mathrm{ha}^{-1}$ of $\mathrm{Cu}$. Moral et al. [25] observed that an application of $210 \mathrm{~kg} \mathrm{ha}^{-1}$ of $\mathrm{N}$ in pig slurry made a contribution of $15.4 \mathrm{~kg} \mathrm{ha}^{-1} \mathrm{Zn}$ and $3.8 \mathrm{~kg} \mathrm{ha}^{-1}$ of $\mathrm{Cu}$. While the amount of $\mathrm{Zn}$ that was contributed by pig slurry in this study was between these reported results, the amount of $\mathrm{Cu}$ that was contributed was always lower, probably due to the limited content of this element in the feed composition and, consequently, in the slurries.

Notably, the HM balance was evaluated considering an application of $200 \mathrm{~kg} \mathrm{~N} \mathrm{ha}^{-1}$, which is close to the maximum amount that is applicable in vulnerable zones according to the European nitrate directive (91/676/CEE). However, in actual practice, the doses that are applied are often higher and can be almost doubled in some areas or for some crops. Increasing the application rate consequently increases the concern about long-term manure applications.

By considering the HM balance in terms of soil enrichment, the results that were obtained highlight that the HM contents in the harvested plants did not increase with slurry application.

Thus, the possible soil enrichment can be assessed in terms of years required to double the soil initial content, assuming that the amounts of HMs that are added in excess of crop uptake are retained in the soils. Figure 6 shows the results of this analysis for $\mathrm{Cu}$ and $\mathrm{Zn}$ that was applied in pig slurry. The time required to apply the same amount of $\mathrm{Zn}$ that is contained initially in the soil is relatively low for soils A and C. This result is in some way expected as these two soils had not been fertilized with manure for many years. Furthermore, the initial Zn content of the two soils, especially that of soil C, was low compared to the other soils.

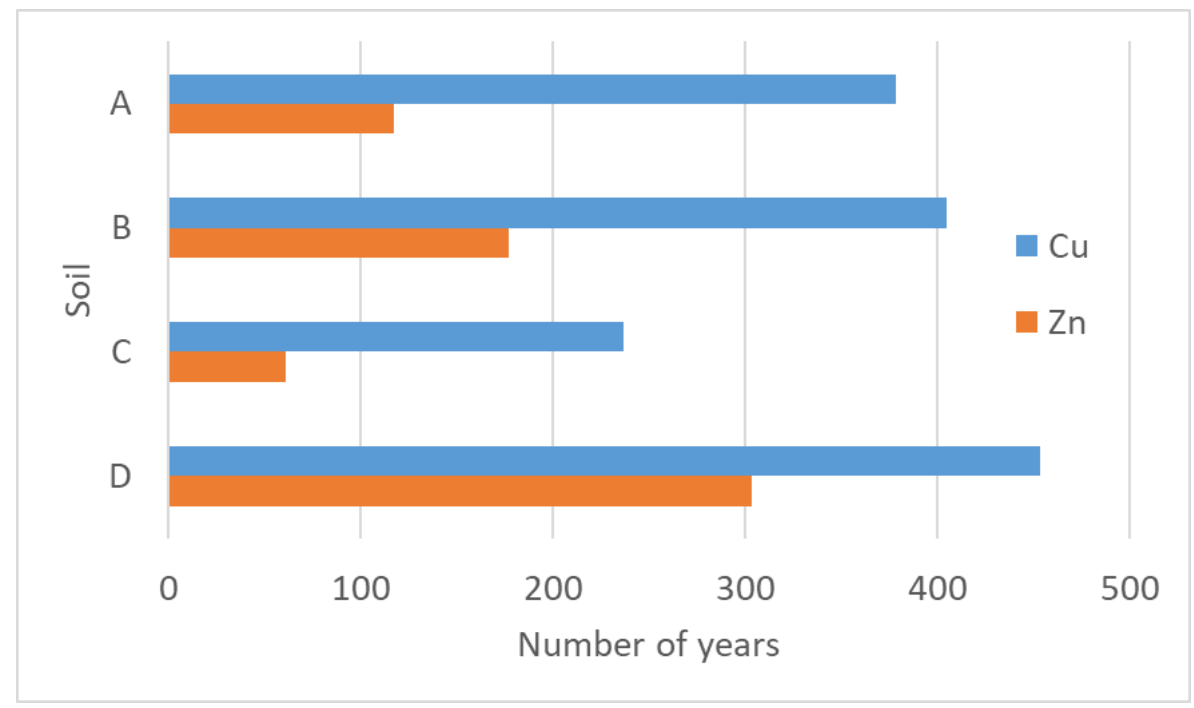

Figure 6. Number of years required for applications of pig slurry (at the rate of $200 \mathrm{~kg} \mathrm{~N} \mathrm{ha}^{-1}$ ) to contribute an amount of $\mathrm{Cu}$ and $\mathrm{Zn}$ equal to the initial content of the different soils (A, B, C, and D).

The enrichment of the soil in terms of $\mathrm{Cu}$ and $\mathrm{Zn}$ is in agreement with the findings of Berenguer et al. [5] who stated that fertilisation with pig slurry causes long-term enrichment of the soil. While this enrichment can affect soil quality, from an environmental point of view, it should be emphasized that soil enrichment can also cause nutrient release to groundwater [8]. However, it is also important to note how atmospheric depositions can affect the HM budget in soil-plant systems, especially in terms of $\mathrm{Zn}, \mathrm{Cu}$, and $\mathrm{Cr}$. In fact, atmospheric deposition can account for $38 \%$ of the accumulation of $\mathrm{Cu}$ and $\mathrm{Zn}$ in some systems [3]. In any case, the estimation of the soil enrichment of HMs related to animal manure application can be used as input for conducting life cycle 
assessments to characterize the potential impacts for agricultural practices, e.g. livestock management or crop production using manure as fertiliser and thus, enables the better assessment of environmental sustainability $[4,32]$.

\section{Conclusions}

The experiments that were carried out, growing two maize hybrids in different soils and with different fertilisations, demonstrated that the shoots had different concentrations of essential $(\mathrm{Cu}$, $\mathrm{Mn}, \mathrm{Zn}$ ) and non-essential (Cr) HMs. Although the interaction among the factors is relevant, the soil characteristics seem to have (as expected) a major role. The effect of organic fertilisation showed a strong interaction with the soils and, in general, reduced the content of $\mathrm{Cu}, \mathrm{Mn}$, and $\mathrm{Zn}$ in the shoots compared with the contents resulting from urea fertilisation. In any case, the influence of the different factors that were investigated in this study on HM contents in shoots should be further investigated to assess the mitigation potential of different fertilisation techniques.

Although we cannot exclude some limitations due to the controlled environmental conditions that were adopted in our research, the potential soil enrichment of the long-term application of livestock manure is clear. The concern is mainly related to the application of pig slurries that have a high content of $\mathrm{Cu}$ and $\mathrm{Zn}$. Based on the experimental results and considering a yearly application of pig slurry at a dose of $200 \mathrm{~kg} \mathrm{~N} \mathrm{ha}^{-1}$, the time required to apply an amount of HM equal to the initial soil content is 60-300 years for $\mathrm{Zn}$ and 240-450 years for $\mathrm{Cu}$, depending on soil type and the initial HM content.

Considering that the introduction of HM into the soil and food chain can have a potential negative effect on environmental quality and on animal and human health, the long-term use of animal manure and slurries with high contents of HM, especially $\mathrm{Cu}$ and $\mathrm{Zn}$, should be carefully considered.

Author Contributions: G.P. and G.A.S. conceived and designed the experiments; G.M. and E.R. performed the experiments; G.P., G.A.S., A.F., G.L. and G.M. analyzed the data; G.L. and E.R. performed the chemical analyses; G.P., G.M., A.F. and G.A.S. wrote the paper.

Funding: This research received no external funding.

Acknowledgments: This research has been self-funded by the Department of Agricultural and Environmental Sciences.

Conflicts of Interest: The authors declare no conflict of interest.

\section{References}

1. Sommer, S.G.; Christensen, M.L.; Schmidt, T.; Jensen, L.S. Animal Manure Recycling: Treatment and Management; John Wiley \& Sons Ltd.: Chichester, UK, 2013; ISBN 9781118676677.

2. Petersen, S.O.; Sommer, S.G.; Béline, F.; Burton, C.; Dach, J.; Dourmad, J.Y.; Leip, A.; Misselbrook, T.; Nicholson, F.; Poulsen, H.D.; et al. Recycling of livestock manure in a whole-farm perspective. Livest. Sci. 2007, 112, 180-191. [CrossRef]

3. Nicholson, F.A.; Chambers, B.J.; Williams, J.R.; Unwin, R.J. Heavy metal contents of livestock feeds and animal manures in England and Wales. Bioresour. Technol. 1999, 70, 23-31. [CrossRef]

4. Leclerc, A.; Laurent, A. Framework for estimating toxic releases from the application of manure on agricultural soil: National release inventories for heavy metals in 2000-2014. Sci. Total Environ. 2017, 590-591, 452-460. [CrossRef] [PubMed]

5. Mantovi, P.; Bonazzi, G.; Maestri, E.; Marmiroli, N. Accumulation of copper and zinc from liquid manure in agricultural soils and crop plants. Plant Soil 2003, 250, 249-257. [CrossRef]

6. Berenguer, P.; Cela, S.; Santiveri, F.; Boixadera, J.; Lloveras, J. Copper and zinc soil accumulation and plant concentration in irrigated maize fertilized with liquid swine manure. Agron. J. 2008, 100, 1056-1061. [CrossRef]

7. Di Salvatore, M.; Carratù, G.; Carafa, A.M. Assessment of heavy metals transfer from a moderately polluted soil into the edible parts of vegetables. J. Food, Agric. Environ. 2009, 7, 683-688. [CrossRef] 
8. He, Z.L.; Yang, X.E.; Stoffella, P.J. Trace elements in agroecosystems and impacts on the environment. J. Trace Elem. Med. Biol. 2005, 19, 125-140. [CrossRef] [PubMed]

9. Bruemmer, G.W.; Gerth, J.; Herms, U. Heavy metal species, mobility and availability in soils. Z. Pflanzenernähr. Bodenkd. 1986, 149, 382-398. [CrossRef]

10. Park, J.H.; Lamb, D.; Paneerselvam, P.; Choppala, G.; Bolan, N.; Chung, J.-W. Role of organic amendments on enhanced bioremediation of heavy metal(loid) contaminated soils. J. Hazard. Mater. 2011, 185, 549-574. [CrossRef] [PubMed]

11. Putwattana, N.; Kruatrachue, M.; Kumsopa, A.; Pokethitiyook, P. Evaluation of Organic and Inorganic Amendments on Maize Growth and Uptake of Cd and Zn from Contaminated Paddy Soils. Int. J. Phytoremediat. 2015, 17, 165-174. [CrossRef] [PubMed]

12. Wang, M.; Zou, J.; Duan, X.; Jiang, W.; Liu, D. Cadmium accumulation and its effects on metal uptake in maize (Zea mays L.). Bioresour. Technol. 2007, 98, 82-88. [CrossRef] [PubMed]

13. Ciura, J.; Poniedziałek, M.; Sekara, A.; Jedrszczyk, E. The possibility of using crops as metal phytoremediants. Polish J. Environ. Stud. 2005, 14, 17-22.

14. Poniedziałek, M.; Sękara, A. Phytoremediation efficiency of crop plants in removing cadmium, lead and zinc from soil. Folia Horticult. 2013, 2, 25-31. [CrossRef]

15. Rascio, N.; Navari-Izzo, F. Heavy metal hyperaccumulating plants: How and why do they do it? And what makes them so interesting? Plant Sci. 2011, 180, 169-181. [CrossRef] [PubMed]

16. Fasani, E.; Manara, A.; Martini, F.; Furini, A.; DalCorso, G. The potential of genetic engineering of plants for the remediation of soils contaminated with heavy metals. Plant Cell Environ. 2018, 41, 1201-1232. [CrossRef] [PubMed]

17. McGrath, S.P.; Zhao, F.J.; Lombi, E. Plant and rhizosphere processes involved in phytoremediation of metal-contaminated soils. Plant Soil 2001, 232, 207-214. [CrossRef]

18. Pilon-Smits, E. Phytoremediation. Annu. Rev. Plant Biol. 2005, 56, 15-39. [CrossRef] [PubMed]

19. FAOSTAT. Available online: http:/ / www.fao.org (accessed on 1 June 2018).

20. Aliyu, H.G.; Adamu, H.M. The Potential of Maize As Phytoremediation Tool of Heavy Metals. Eur. Sci. J. 2014, 10, 30-37.

21. Wang, S.; Wu, W.; Liu, F.; Liao, R.; Hu, Y. Accumulation of heavy metals in soil-crop systems: A review for wheat and corn. Environ. Sci. Pollut. Res. 2017, 24, 15209-15225. [CrossRef] [PubMed]

22. U.S. EPA. Method 3051A. Microwave Assisted Acid Digestion of Sediments, Sludges, Soils and Oils; U.S. EPA: Washington, DC, USA, 2007.

23. Rice, E.W.; Baird, R.B.; Eaton, A.D. (Eds.) Standard Methods for the Examination of Water and Wastewater; American Public Health Association, American Water Works Association, Water Environment Federation: Washington, DC, USA, 2012; ISBN 9780875530130.

24. Martínez-Suller, L.; Azzellino, A.; Provolo, G. Analysis of livestock slurries from farms across Northern Italy: Relationship between indicators and nutrient content. Biosyst. Eng. 2008, 99, 540-552. [CrossRef]

25. Moral, R.; Perez-Murcia, M.D.; Perez-Espinosa, A.; Moreno-Caselles, J.; Paredes, C.; Rufete, B. Salinity, organic content, micronutrients and heavy metals in pig slurries from South-eastern Spain. Waste Manag. 2008, 28, 367-371. [CrossRef] [PubMed]

26. Dalcorso, G.; Manara, A.; Furini, A. An overview of heavy metal challenge in plants: From roots to shoots. Metallomics 2013, 5, 1117-1132. [CrossRef] [PubMed]

27. Asada, K.; Toyota, K.; Nishimura, T.; Jun-Ichi, I.; Hori, K. Accumulation and mobility of zinc in soil amended with different levels of pig-manure compost. J. Environ. Sci. Health Part B Pestic. Food Contam. Agric. Wastes 2010, 45, 285-292. [CrossRef] [PubMed]

28. Tambone, F.; Adani, F. Nitrogen mineralization from digestate in comparison to sewage sludge, compost and urea in a laboratory incubated soil experiment. J. Plant Nutr. Soil Sci. 2017, 180, 355-365. [CrossRef]

29. Shanker, A.K.; Cervantes, C.; Loza-Tavera, H.; Avudainayagam, S. Chromium toxicity in plants. Environ. Int. 2005, 31, 739-753. [CrossRef] [PubMed]

30. Wang, M.; Liu, R.; Lu, X.; Zhu, Z.; Wang, H.; Jiang, L.; Liu, J.; Wu, Z. Heavy Metal Contamination and Ecological Risk Assessment of Swine Manure Irrigated Vegetable Soils in Jiangxi Province, China. Bull. Environ. Contam. Toxicol. 2018, 100, 634-640. [CrossRef] [PubMed] 
31. Tutic, A.; Novakovic, S.; Lutovac, M.; Biocanin, R.; Ketin, S.; Omerovic, N. The heavy metals in agrosystems and impact on health and quality of life. Maced. J. Med. Sci. 2015, 3, 345-355. [CrossRef] [PubMed]

32. Laurent, A.; Owsianiak, M. Potentials and limitations of footprints for gauging environmental sustainability. Curr. Opin. Environ. Sustain. 2017, 25, 20-27. [CrossRef] 